\title{
Green Growth and Business Opportunity in India
}

\author{
Amar Nath Bhadra ${ }^{1, *}$, Subhendu Podder ${ }^{2}$ \\ ${ }^{1}$ Government of West Bengal, Kolkata, India \\ ${ }^{2}$ Jindal Power Limited, Gurgaon, India
}

Copyright $\mathrm{O} 2018$ by authors, all rights reserved. Authors agree that this article remains permanently open access under the terms of the Creative Commons Attribution License 4.0 International License

\begin{abstract}
India is one of the fastest growing economies in the world and is moving ahead with developmental path, and process. The Sustaining a fast-paced growth rate and driving a comprehensive development requires addition of major infrastructures like Power, Road, Communication, and Transportation. To ensure inclusive growth infrastructure should also grow side by side but to ensure the sustainability that growth shall be in the form of Green way. The rapid industrialisation and anthropogenic activities have vitiated the atmosphere and ailments like Chronic Obstructive Pulmonary Disease (COPD), Cancer, and other vector-borne diseases have increased. Green House Gases (GHGs) that emits from coal-based combustions, vehicle exhaust, and irresponsible use of pesticides is causing a significant damage in the quality of atmosphere. The "Right to inhale fresh air" and the "Right for safe living on the Earth" shall be new demand of humanity. As a responsible leadership, The Government of India not only has become a signatory of Conference of Parties (COP-21) but also quickly and simultaneously implementing the eight points of India's Intended Nationally Determined Contributions (INDC). India recognises the need for sourcing the additional energy requirement mostly from the renewable sources like Solar, Wind, while balancing the gap through Advanced Ultra Super Critical Technology (AUSCT) to ensure the Green Growth. The obvious fall-out of the above will increase the business opportunity in renewables in one hand and obsolescence of existing coal based thermal power generating plants on the other hand. Authors intend to indicate that innovation is going to convert the apparent challenges into new business opportunities through "Decommissioning", "Disposal" and "Logistics" while absorption of advanced technologies and compliance to stringer environmental norms will also open up new vistas of business, driving the growth wheel in a green way.
\end{abstract}

Keywords Make in India, Safe-living, Green Growth

\section{Introduction}

The Government of India is determined to ensure a sustained growth trajectory through progressive increase in share of manufacturing hub in the Gross Domestic Product (GDP) in-line with the other developing countries. 'Make in India', a bold and a major national initiative which focuses on making the India a global manufacturing hub through various innovative, additive and corrective measures like cutting down time for statutory clearances, developing key infrastructure and use of digital platform to answer quarries of investors within 48 hours. The growth of manufacturing sectors in a country that ensures sustainable growth of employment opportunities for the youth and professionals leading to creation of greater purchasing power of the people which further drives the demand wheel to continue.

India is set to become the world's youngest country, by 2030 , with $64 \%$ of its population in the working age group ${ }^{[1]}$ while the countries like Japan and China will be aging ${ }^{[2]}$. This demographic potential would create an additional $2 \%$ growth of Gross Domestic Product (GDP). India to become the most preferred manufacturing destination of investors across the globe, soon, according to the expert's assessment.

India has already been taken major steps to curb the expected increases in the Green House Gases (GHG) emissions, to increase the efficiency through various monitoring measures, including launching of Perform Achieve and Trade (PAT), with which it ensures proper use of resources, reduce consumption, and accelerate the adoption of clean technologies. With the anticipated growth of manufacturing sector, the India's Green House Gases (GHG) emissions may increase by 3.5 times unless innovative energy resourcing is adequately adopted in the process. An estimate by the McKinsey indicates that by 2030 the Green House Gases (GHG) emissions in India will reach to 5.7 billion metric tons of carbon dioxide equivalent $\left(\mathrm{CO}_{2} \mathrm{e}\right)$ from 1.6 billion in $2005,{ }^{[3]}$.

India has through enough to support the expected continued rapid growth, while securing sustainability that exceeds current expectations. 


\section{Role of Electricity in Growth}

The invention of fire may be considered as a major milestone in the journey of development of science and was able to bring a disruptive change in quality of life of the ancient civilization. This discovery paved way to exploration of the tremendous potential. Major inventions of science focused on harnessing energy and converting the same from one form to another for achieving mechanical work. From the time immemorial, the human race has survived, grown, flourished and prospered on the basis of energy harnessed, converted in usable form and utilized. The discovery of electricity has paved way to the most flexible source of energy. From powering consumer appliances, to multi-gear machines that manufacture and assemble goods and even certain artificial intelligence in the form of computers and modern robotics, electricity is synonymous with power. Presently, in many documents, the per capita consumption of electricity is considered in measuring the human development index.

\section{Present Scenario of Power Generation}

The electricity sector in India is growing leaps and bounds, exhibiting great dynamism and exponential growth, especially post enactment of Electricity Act 2003. Private sector investments started flowing heavily in large sized utility power generation beside the state and central sector investments.

The objective of the Electricity the Act, 2003 is to introduce competition, protect consumer's interests and provide power for all. The aim of the act is to push the sector onto a trajectory of sound commercial growth and to enable the States and the Centre to move in harmony and coordination. The Act also paved way for National Electricity Policy, Rural Electrification, Open access in transmission, phased open access in distribution, formation of the State Electricity Regulatory Commissions (SERCs), license free generation and distribution, power trading, mandatory metering and stringent penalties for theft of electricity. The Electricity Act, along with the subsequent amendments in 2003 and in 2007, is a comprehensive legislation replacing Electricity Act 1910, Electricity Supply Act 1948 and Electricity Regulatory Commission Act, 1998.

The conscious decision to incentivise the investors in electricity business was a major strategic step to boost the availability of electricity for industry, commerce and domestic. The continuance concept of cross subsidisation to agricultural tariff from the other segment was indicative of the Governments policy to promote the agricultural activities / agro business and thereby extending support to the farmers towards their growth and prosperity.

The Overall generation (including generation from grid connected renewable sources) in India has increased from 1173.458 Billion Units (BU) during 2014-15 to 1173.603 BU during the year 2015-16 and 1242.010 Billion Units (BU) during 2016-17. The snap-shot of category wise generation during the recent years [4] is given in Table-1 below;

Table 1. Year wise percentage growth of power

\begin{tabular}{|c|c|c|c|}
\hline YEAR & $\begin{array}{c}\text { CONVENTIONAL } \\
(\%)\end{array}$ & $\begin{array}{c}\text { RENEWABLE } \\
(\%)\end{array}$ & $\begin{array}{c}\text { TOTAL } \\
(\%)\end{array}$ \\
\hline $2008-09$ & 2.7 & - & - \\
\hline $2009-10$ & 6.6 & - & - \\
\hline $2010-11$ & 5.56 & - & - \\
\hline $2011-12$ & 8.11 & - & - \\
\hline $2012-13$ & 4.01 & - & - \\
\hline $2013-14$ & 6.04 & - & - \\
\hline $2014-15$ & 8.43 & - & - \\
\hline $2015-16$ & 5.64 & 6.47 & 5.69 \\
\hline $2016-17$ & 4.72 & 23.97 & 5.8 \\
\hline $\begin{array}{c}\text { 2017-18 } \\
\text { (Nov) }\end{array}$ & 4.04 & 17.04 & 4.95 \\
\hline
\end{tabular}

Supported by the Government encouragement and the friendly policy initiatives lot of capacities have been added leading to narrowing down the demand-supply gap in the sector. In line with the long term vision of Government of India for promoting "Green Power" India quadrupled its solar-generation capacity from 2,650 MW on 26 May 2014 to $12,289 \mathrm{MW}$ on 31 March $2017^{[6]}$. The trend on the addition of Solar Power Generation capacity in last few years is given below;

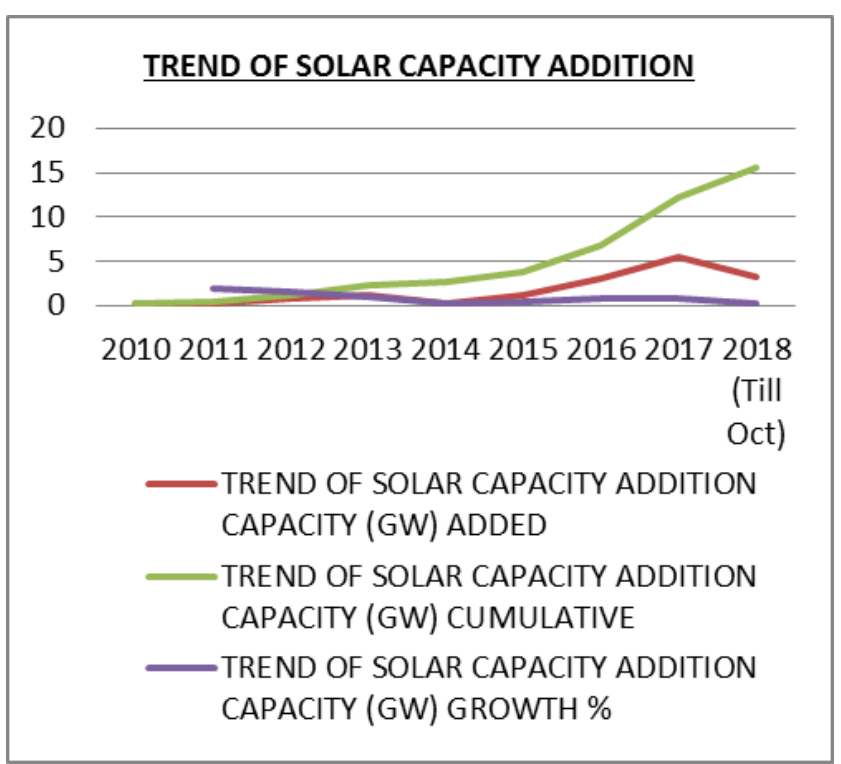

Figure 1. Yearly Trend of Solar Capacity Addition

Ideally, any power system should have a judicial mix of 
various possible/commercial sources but even having the second largest coal reserve the resolution of Government of India to vigorously increase proportion of Green Power is really commendable and indicates the responsibility of the present generation to the price today for the sustainability of the future generations, in line with the traditional Indian values into ensure safe-living on the planet Earth. The present installed capacities in various categories of electricity generation are as under ${ }^{[5]}$;

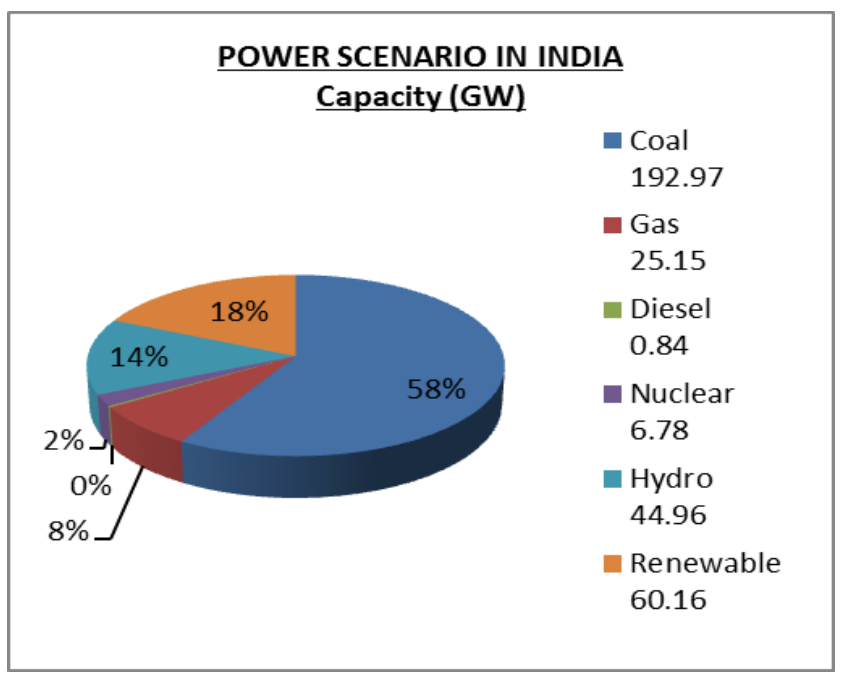

Figure 2. Source wise percentage installed capacity

A conservative estimate by experts indicates that the electrical energy demand for 2021-22 is expected to be at least 1,915 Tera Watt Hours, with a peak electric demand of $298 \mathrm{GW}$. It may be further noted that for a demand of about $300 \mathrm{GW}$ will require about $400 \mathrm{GW}$ of installed capacity to account for plant availability, infrastructure maintenance, spinning reserve and losses.

\section{Demand and Supply Scenario}

It may be re-called that during the fiscal year 2014-15, the electricity generated in utility sector was $1,030.785$ billion KWh with a short fall of requirement by 38.138 billion KWh (-3.6\%) against the 5.1\% deficit anticipated. The peak load met was $141,180 \mathrm{MW}$ with a short fall of requirement by $7,006 \mathrm{MW}(-4.7 \%)$ against the $2.0 \%$ deficit anticipated. In a May 2015 report, India's Central Electricity Authority anticipated, for the 2015-16 fiscal year, a base load energy deficit and peaking shortage to be $2.1 \%$ and $2.6 \%$ respectively. Southern and North Eastern regions are anticipated to face energy shortage up to $11.3 \%$. The marginal deficit figures clearly reflect that India would become electricity surplus during the 12th five-year plan period. Authors opine that the actual demand will be much more than anticipated/estimated due to following reasons;

i). The Government of India either through Power Grid Corporation of India (PGCIL) or through Tariff Based Competitive Bidding (TBCB) is creating the required EHV/EEHV network of transmission corridor to facilitate flow of electricity to the consumption zones.

ii). India's manufacturing sector is likely to grow faster than in the past due to push from the "Make in India" initiative.

iii). Domestic demand will increase more rapidly as the quality of life is expected to increase many fold in near future.

iv). The most coveted programme namely "Power for All" is likely to connect about 125,000 villages to India's electricity grid.

v). The suppressed demand due to blackouts, load shedding and unstable supply is likely to be surfaced when stable and quality power will be available at affordable price.

\section{Make in India - The Vision}

The contribution of manufacturing industry to the national GDP is around $15 \%$ which needs to be enhanced to $25 \%$ or more in line with developing nations of Asia. The methodology of achieving the desired goal will be multipronged and targeted to be pursued as matter of faith. India is set to become a new global manufacturing hub. Innovation and technology absorption shall be directed to skill enhancement, employment generation, tax-net widening, high quality standards, attract capital, with minimum environmental impact is expected to play a key role and attract a lot of entrepreneurial talent, including foreign direct investment (FDI) in various fields along with creation of innumerable job opportunities. The showcasing of a technology-savvy Digital India along with make in India has opened up additional dimensions leading to more and more transparency and better ease-of-doing business. Lot of new business areas is being opened due to prospective retirement of old units.

\section{Opportunities \& Challenges}

As a result of these initiatives, the estimated growth rate of India is around 7-8 \% till 2030. Accordingly, during the same period lot of physical assets including power plants, factories, , commercial and residential estates, vehicles, roads, bridges, railways, logistic parks and many more associated infrastructure will come-up. Obviously, organic growths will also bring many challenges to the environment and economy. The demand for more resources will increase the import leading to increased economic activity in the port causing possibility of significant increase in the pollution level. Enhanced life-style related expenditure will bring positive economic activities, but may lead to increase in crude import and causing a strain on the foreign currency exchequer. The Per capita electricity consumption is often used to indicate the 
state of human development index. In order to serve the increased economic activities, the power generation capacities will have to be increased at the same pace which will impel a corresponding increase in greenhouse-gas (GHG) emission, unless proper and planned measures are initiated significantly.

\section{Green Growth - Indian Regulation}

India feels that green growth promotes inclusivity ${ }^{[7]}$. The Constitution of India contains specific provisions for the protection and improvement of environmental quality. Article 48-A of the Constitution says that "the state shall endeavour to protect and improve the environment and to safeguard the forests and wild life of the country." Article 51-A (g) says that "It shall be duty of every citizen of India to protect and improve the natural environment including forests, lakes, rivers and wild life and to have compassion for living creatures."

These provisions highlight the national conscience on the importance of environment protection. The National Environment Policy of the Ministry of Environment, Forests, and Climate Change (MoEF \& CC) highlights important principles around sustainable development such as social justice, polluter pays, and entities of incomparable value. The National Action Plan on Climate Change (NAPCC) along with the State Action Plan on Climate Change is important milestones for mainstreaming climate in development processes at the national and state levels. The current eight missions are on the areas of solar energy, energy efficiency, sustainable habitat, sustainable agriculture, Green India, water, Himalayan ecosystem, and strategic knowledge. The government is proposing to set up new missions on wind energy, health, waste-to-energy, coastal areas, and also redesigning the National Water Mission and National Mission on Sustainable Agriculture. Government of India has already exhibited sensitivity towards global environment by voluntarily announcing INDC and being a signatory to COP-21, in addition to internal discipline, sensitivity and commitment.

\section{INDC - India's Eight-Point}

The Government of India has always played a pivotal role in ensuring the sustainability of the global environment. The same has been reaffirmed by quickly finalizing and voluntarily announcing the following, as a part of INDC;

i). To put forward and further propagate a healthy and Sustainable way of living based on traditions and values of conservation and moderation.

ii). To adopt a climate friendly and a cleaner path than the one followed hitherto by others at corresponding level of economic development. iii). To reduce the emissions intensity of its GDP by 3335 per cent by 2030 from 2005 levels

iv). To achieve about 40 per cent cumulative electric power installed capacity from non- fossil fuelbased energy resources by 2030 with the help of transfer of technology and low cost international finance including from Green Climate Fund (GCF).

v). To create an additional carbon sink of 2.5-3 billion tonnes of $\mathrm{CO}_{2}$ equivalent through additional forest and tree cover by 2030 .

vi). To better adapt to climate change by enhancing investments in development programmes in sectors vulnerable to climate change, particularly agriculture, water resources, Himalayan region, coastal regions, health, and disaster management.

vii). To mobilize domestic and new and additional funds from developed countries to implement the above mitigation and adaptation actions in view of the resource required and the resource gap.

viii). To build capacities, create domestic framework and international architecture for quick diffusion of cutting edge climate technology in India and for joint collaborative research and development for such future technologies.

\section{New Norms - Compliance Issues}

Immediately after notification of the new environmental norms the Central Electricity Authority (CEA) and Regional Power Committees (RPCs), under the Ministry of Power (MoP), started discussions with the Power Producers, Engineering Consultants, Manufacturers, Erectors and other stakeholders are to formulate the most viable implementation plan without risking the availability of adequate number of generating stations till all the stations become fully complied. An analysis on the age and performance of the existing power station reveals that;

i). Many power plants surpassed their useful life of 25 years.

ii). Most of these old units are less than $110 \mathrm{MW}$ units

iii). As on March 31, 2017, the capacity of coal-based thermal plants that are more than 25 years old is approximately 39,296 MW.

iv). These old units consume more coal, produce less power and are a major contributor to air pollution.

v). PLFs of these plants can go below $40 \%$.

vi). They have high auxiliary consumption as well.

A significant step has already been initiated by the Ministry of Environment, Forest and Climate Change (MoEF \& CC) through its notification mandating compliance of new norms regarding Oxides of Sulphur (SOx), Oxides of Nitrogen (NOx), Mercury (Hg) and Water Consumption norms. 


\section{Business Opportunity}

The conscious decision of Government of India to become the signatory of Conference of Parties (COP-21) has created many new dimensions of the business opportunities in the future. Immediately after the notification a detailed survey was conducted by various research organisation either of their academic interest or engaged by prospective business houses who were interested to reap the benefit of emerging opportunities due to change in regulations, to assess the impenetrability and impact of associated issues. One such report ${ }^{[8]}$ concluded that units aged more than 25 years may not be techno-commercially feasible to install improved emission control equipment to fully comply with the new environmental norms. Such research reports also opined that those old and aged units should be retired so that the comparatively younger units will be able to ensure a better utilisation factor to recover their additional investments that would be required to comply with the improved environmental norms. Units aged between 17 years to 25 years will be the most sensitive to investments, in terms of both adaptability and recoverability, as shown in Figure-3(a) and 3(b) below;

\section{Thermal Power Capacity (MW) Breakup by Unit Age}

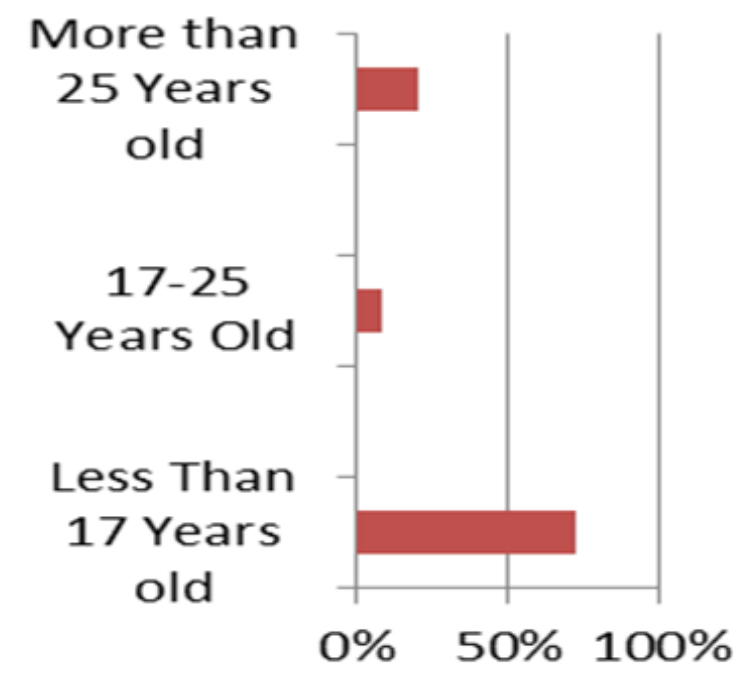

Figure 3 (a).
Thermal Power Capacity (No of Units) Breakup by Age

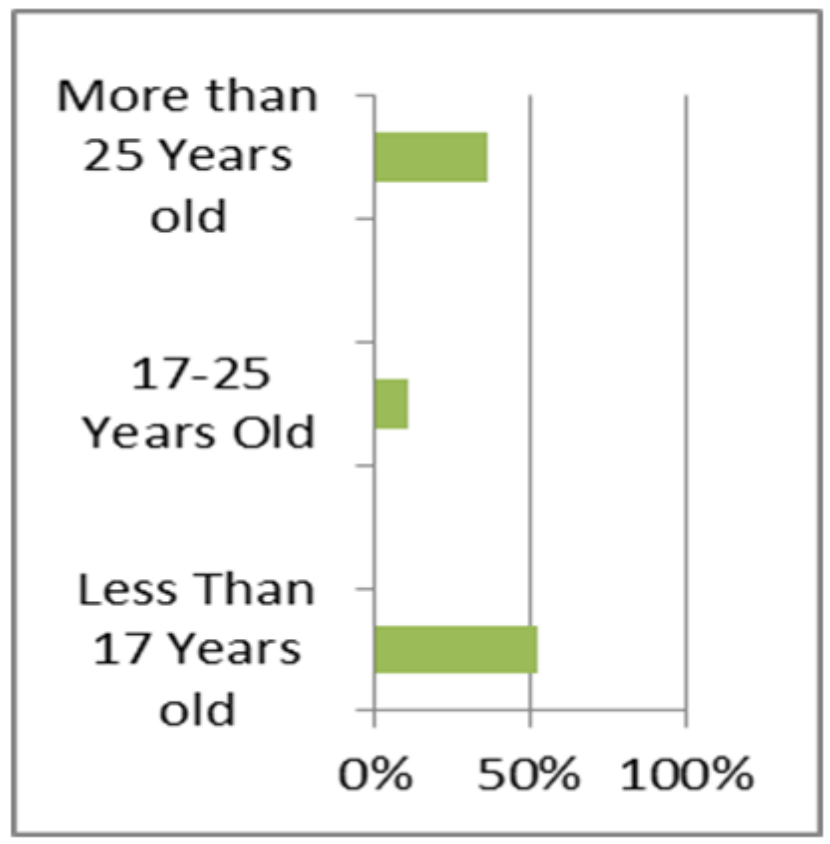

Figure 3(b).

Lot of investments is offing to comply with the new norms. Capital investment of around Rs 1,00,000 crore would be required to install mitigation measures ${ }^{[9]}$. Also, some of the existing units (nearly $55000 \mathrm{MW}$ ) will be techno-economically unviable for such upgrades and eventually they will be retiring to pave way for new, less polluting advanced ultra-super critical units. In both the cases the manufacturing as well as service sectors will get a booster. Some the consequent benefits of above are;

i). Thanks to the initiative of Government of India that facilitated the organic growth of renewable capacity.

ii). In the coming years a lot of old and in-efficient units will retire either by choice or by regulation. CEA has already indicated the possibility of retiring units having ages more than 25 year which at present accounts for around $39 \mathrm{GW}$.

iii). The Central and State utilities are already geared up to utilize those land for installations of the more efficient super-critical units which can add around $100 \mathrm{GW}$ thermal capacity. 
iv). Both due to implementation of new environmental norms and replacing the retired units by super-critical technology, we can achieve less SOx, $\mathrm{NOx}, \mathrm{PM}$, and $\mathrm{CO}_{2}$ emission.

v). The decision for retiring old and inefficient units will not only improve environment but also is going to reduce the burden of ultimate consumer who actually pays for those idle assets and inefficient economics. Overall pool price/weighted average cost of power of every DISCOM will tend to reduce facilitating the SERCs to reduce the allowable price.

vi). The coal based thermal power plans will continue to be relevant in India as the prime source of electricity not only because of cost but also on many factors including the 'round-the-clock' availability and predictability.

Conventionally, we would be tempted to consider that the new situation would create a new business area that includes;

a Decommissioning and Disposal of retired plants

b Super-Critical / Ultra-Super-critical capacity addition

c Environmental compliance solutions and Equipment.

\section{Business - Sustainability}

India needs to find out an easy way of financing, regulation, skill development, and technology adoption and business-model certainty. Some solutions could be costlier at present but would create a sustainable environment for our next generation. India is likely to maintain its expected rate of growth over the next 20 years as the need for reducing its GHG emissions and increasing its energy security has been well accepted by both government and the business community. By accelerating large-scale adoption of new technologies, enabling sustainable process, working on efficiency improvement and lowering resource demand India could decrease operating costs for many businesses. All these will benefit the end consumers leading to greater consumption and enlarged market. To set a new standard for sustainability, all minds should focus on the following;

1) Increase in energy efficiency in industry, vehicles, and appliances;

2) Accelerating the transformation of its power sector to adopt clean technology;

3) Building green infrastructure for urban habitats and transportation; and

4) Establishing sustainable agriculture and forestry practices.

5) Conducting regular audit and ensure compliance to global standards

6) Inculcating green habits to our children.

\section{Other Reasons of GHG Load}

Out of several reasons for GHG emission small-scale diesel generators used to meet power requirement are heavily responsible. A stable and a reliable power supply can eliminate the requirement of such diesel generators to run. Authors have their personal experience that in many residential societies located in important cities runs diesel generators for 4-6 hours per day throughout the year due to frequent power cuts from the distribution companies. The distribution companies should focus on providing uninterrupted power supply to all the consumers who are using costly DG set's power. DG sets consume nearly 15 million tons of diesel oil for running such diesel sets ${ }^{[10]}$. Another important but most neglected area is to provide clean coal to power plants. Government of India should ensure that $100 \%$ of the coal supplied to power plants are first washed which will not only reduce the consumption but also will open-up new business opportunity for entrepreneurs and employment opportunity for the mass.

\section{Green Growth - Consequences}

Every coin has two sides. With the increasing proportion of renewable energy capacity in to system, a new threat of creating idle capacity and bearing the cost of that is expected to come. In other part of the world, especially where lot of renewable energy capacity has already been added thermal capacities are compensated for idling. In order to remain cost-efficient, the existing plants would go for adopting a more efficient part-load performance of the units, paving way for business the engineering companies.

\section{Winds of Change}

Indian Railways, the largest single consumer of electricity, who consumes about $2 \%$, has now decided to complete electrification of rail network by 2020 , ahead of schedule, for which the demand expected to triple by 2030 . The Rs 41,000 crore plans would involve phasing out diesel engines in the next three years whereby all trains will run only on electric locomotives. This is good news for the power industry which is currently facing a 'surplus'. On the other hand, the oil marketing companies (OMCs) may now be spending sleepless nights given that railways is the country's single largest consumer of high speed diesel and with the electrification drive now being fast tracked, the OMCs will be forced to look at alternate suppliers and markets for supplying diesel. However, the renewable sector will not be complaining as the railway plans to source about 1,000 MW solar power under its Solar Mission and about $200 \mathrm{MW}$ of power from windmills. Further, the railway may source a quarter of its power needs from renewable energy sources moving towards its goal of $5 \mathrm{GW}$ of solar by 2025 . The cost of renewable 
power in India has hit a record low. Solar tariffs have already seen a record low of Rs 2.44 per unit earlier this year and the wind tariffs have now also followed suit. In the second round of auction conducted by the government in October, wind power tariff hit a new low of Rs 2.64 a unit for 1,000 MW capacities. Renewable energy in India has now turned cheaper than coal-based power. Today, the wind energy industry is in transition from feed-in tariff (FIT) to competitive bidding. India is also going full throttle in promoting energy efficiency, which is the quickest, cheapest and cleanest way to extend energy supplies. As the fossil fuel reserves are finite and fast depleting, sustainability of energy sector can be ensured only through adoption of large scale energy efficiency improvements. Thus, the government has been trying to promote greater energy efficiency through various policy measures and the use of the super critical technology boilers. The Government is going to introduce further pricing and regulatory reforms to attract enhanced foreign and private investment into the oil and gas sector as it seeks to give a fillip to domestic hydrocarbon production and build infrastructure like LNG import terminal and lay gas pipeline to address supply bottlenecks, as both availability and affordability of energy are going to be equally crucial.

\section{Wild Thought}

Independent Power Producers have invested a sizable quantum of money (both Equity and Debt) expecting a sustainable return but they need a level playing field which can't be logically ensured, if all the facilities are extended to long term PPA holders. Unless some measures are immediately taken to ensure reasonable return of the IPPs a complex socio-economic disaster may lead to large-scale un-employment and NPA leading to further complications on the economy of the country, where the senior citizens are dependent on either of their interest income or on income of dependent, which will be severely hit. Lot of existing power plants is being acquisitioned by central/state sector creating a prospect of further availability of power and employment generation.

\section{Future of Coal Based Power}

The CEA has stated in the draft National Electricity Plan that no new coal based power plants are required in the country at least till 2027, other than the $50 \mathrm{GW}$ under-construction capacities. The country's peak power demand is projected to grow to $235 \mathrm{GW}$ in FY 2021-22 from $159 \mathrm{GW}$ in FY 2016-17 at a CAGR of 8\%. However, this estimate is $17 \%$ lower than the projections made in the year 2012. Low power demand from the State Distribution Companies will mean that there is no need for new coal based power plants in the country up to 2027 , thereby making it easier for the country to fulfill its Intended
Nationally Determined Contributions (INDC) under the Paris Agreement. India's INDC commitments include reduction in the emissions intensity of its GDP by 33 to 35 per cent by 2030 from 2005 level and to create an additional carbon sink of 2.5 to 3 billion tons of $\mathrm{CO}_{2}$ equivalent through additional forest and tree cover by 2030 . The rapidly evolving power scenario presents a need to bring the various stakeholders under a single umbrella to deliberate on the most relevant issue "Future of Coal Based Power Generation in India" which will help in easing the uncertainty in the minds of Project Developers, EPC Contractors and Financial Institutions regarding the future of coal based power plants in the country, prevailing low PLF of the power plants and the likely power scenario in 2030.

\section{Recommendations}

There is no doubt that in India Coal Based Thermal Power will continue to be the major source of electricity but having committed to ensure sustainability of the environment and to ensure safe-living on earth without stalling the development process we need to continually research on the technology to reduce the GHG production from the coal based power stations. As government is indicating to force retirement of the plants which will be non-compliant to the new environmental norms a policy should also be formulated to progressively switch to super-critical to ultra-super-critical to advanced ultra-super-critical technology as a time bound mandate. The existing producers may make a hue and cry on the pretext of increased capital cost but that can be largely off-set by the reduced operating cost allowing our future generation to breathe safely, which is invaluable. India should also consider serious research on exploration of Geothermal Energy and Biomass Energy utilisation. Geothermal Energy is a kind of thermal energy generated and stored in the crust of the mother Earth. Thermal energy is the energy that determines the temperature of matter. India's geothermal energy installed capacity is experimental. Commercial use is insignificant. According to some ambitious estimates, India has a potential of $10,600 \mathrm{MW}$ in the geothermal provinces but it still needs to be exploited. India has potential resources to harvest geothermal energy significantly. In Biomass Energy all kinds of biomass including bagasse, forestry and agro \& agricultural residue are used as fuel to produce electricity. Nearly 750 million tons of non-edible (by cattle) biomass is available annually in India which can be put to use for higher value addition. Promoting biomass energy not only opens up a new method of generating green power it also helps in promoting the domestic hygiene and prevention of unfortunate death of Cattle due to swallowing of non-bio-degradable which often get mixed with domestic waste. 


\section{Conclusions}

For India to achieve development objectives, its economy should continue to grow. But for a country like India, where development is an imperative, environmental consequences can be substantial as it will place serious constraints on natural resources such as land, water, minerals, and fossil fuels, driving up energy and commodity prices. The extent to which its economy will "grow green" will depend on its ability to reduce the quantity of resources required over time to support economic growth that leads to enhancement of social equity and job creation. Green growth could play an important role in balancing these priorities. However, managing fiscal deficits and public debts are two key challenges for national policy making, which could make technological change required for green growth more difficult. Fiscal considerations and trade balance will also continue to be important drivers for shaping India's macro-economic policy. Hence, it becomes essential to understand and maximize the development benefits, such as on such as income, energy access, and trade, of green growth interventions across all key sectors.

\section{Acknowledgements}

The Authors deeply acknowledge the support and encouragement received from our family members along with Er. P. K. Das for his constructive suggestions.

\section{REFERENCES}

[1] Youth in India, 2017, Central Statistics Office, Ministry of Statistics and Programme Implementation, Government of India, https://www.mospi.nic.in/YYouth_in_India-2017

[2] World Population Ageing, 2015, Department of Economic and Social Affairs, Population Division, United Nations, New York, https://www.un.org /publications/.../WPA2015

[3] India: Taking on the Green-Growth Challenge, https://www.greengrowthknowledge.org/.../India_taking_o n_the_GG_challenge_Mckinsey.p..

[4] Power Ministry of India website, powermin.nic.in

[5] Central Electricity Authority of India website, cea.nic.in

[6] MNRE website, mnre.gov.in

[7] Ministry of Finance, Government of India, Thirteenth Finance Commission 2010-2015 - PRS, para 3.15, https://www.prsindia.org/uploads/media/13 financecommiss ionfullreport.pdf

[8] Research findings of AVALON consulting, 2017; internal document.

[9] Infraline Research on Business Opportunity on New Environmental Norms; www.infraline.com

[10] 17th Electric Power Survey of India; https://timesofindia.indiatimes.com/topic/17th-electric-pow er-survey 